Original Research Paper

\title{
Penguatan Ekonomi Masyarakat Melalui Pemanfaatan Lahan Pekarangan di Desa Merembu, Lombok Barat
}

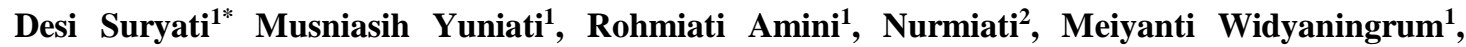 \\ Bukhori Muslim \\ 1 Program Studi Ilmu Pendidikan Ekonomi, Fakultas Keguruan dan Ilmu Pendidikan, Universitas \\ Nahdlatul Wathan Mataram, Indonesi \\ ${ }^{2}$ Program Studi Pendidikan Biologi, Fakultas Keguruan dan Ilmu Pendidikan, Universitas Nahdlatul \\ Wathan Mataram, Indonesia \\ ${ }^{3}$ Program Studi Pendidikan Bahasa Indonesia, Fakultas Keguruan dan Ilmu Pendidikan, Universitas \\ Nahdlatul Wathan Mataram, Indonesia
}

https://doi.org/10.29303/jpmpi.v3i2.1315

Sitasi: Suryati, D., Yuniati, M., Amini, R., Nurmiati., Widyaningrum, M \& Muslim. B. (2022). Penguatan Ekonomi Masyarakat Melalui Pemanfaatan Lahan Pekarangan di Desa Merembu, Lombok Barat. Jurnal Pengabdian Magister Pendidikan IPA, 5(1)

\section{Article history}

Received: 10 Noveber 2021

Revised: 17 Desember 2021

Accepted: 30 Desember 2021

*Corresponding Author: ${ }^{1}$ Program Studi Pendidikan Ekonomi, Fakultas Keguruan dan Ilmu Pendidikan, Universitas Nahdlatul Wathan Mataram, Indonesia;

Email: desisuryatiunw@gmail.com
Abstrak: Kondisi ekonomi masyarakat yang mulai terpuruk sejah masuknya pandemi Covid 19 menjadi perhatian semua pihak. Penguatan ketahanan pangan mulai gencar dilaksanakan dalam upaya penanggulangan permaslahan ekonomi pada setiap rumah tangga dengan memanfaatkan semua potensi sumber daya yang ada di sekitarnya dalam hal ini adalah lahan pekarangan. Metode yang digunakan adalah penyuluhan berupa sosialisasi, diskusi, Tanya jawab. Hasil Pengabdian menunjukkan bahwa semua peserta yang hadir sangat antusias mengikuti kegiatan pengabdian yaitu sosialisasi, diskusi dan Tanya jawab tentang fungsi dan manfaat lahan pekarangan serta upaya yang dapat dilakukan untuk menambah penghasilan atau pendapatan pada masyarakat Desa Merembu Kabupaten Lombok Barat. Kesimpulan kegiatan pengabdian sebagai berikut: semua peserta yang terdiri dari ibu ibu rumah tangga, pemuda, dan masyarakat maupun orang tua yang ada di Desa Merembu Kabupaten Lombok Barat sangat antusias mengikuti seluruh rangkaian kegiatan dengan memberikan respon yang positif selama kegiatan pengabdian berlangsung. Tim Pengabdian memaparkan dan memberikan sosialisasi pemanfaatan lahan pekarangan sehingga bisa menghasilkan tambahan pendapatan bagi masyarakat dan peserta aktif menanyakan hal-hal yang belum jelas dari materi yang telah di sampaikan. Pemanfaatan lahan pekarangan tidak hanya untuk digunakan pada bidang pertanian namun juga bisa digunakan pemanfaatannya untuk pengembangan usaha produksi dengan skala mikro, membuat bengkel mini, tempat pencucian motor atau mobil Pada akhir kegiatan ini perserta dapat memiliki pengetahuan yang baik tentang pemanfaatan lahan pekarangan sebagai tambahan penghasilan atau pendapatan masyarakat di Desa Merembu Kabupaten Lombok Barat

Keywords: Ekonomi Masyarakat, Pemanfaatan, Lahan Pekarangan

\section{Pendahuluan}


$\mathrm{P}$ erekonomian masyarakat merupakan salah satu permasalahan yang muncul akibat dari covid 19 selain dampak kesehatan yang memberikan efek terhadap tingginya tingkat kematian akibat penyebaran virus yang hampir mengenai seluruh masyarakat di Indonesia. Sejalan dengan data nasional, data pada Pemprov NTB juga menujukkan grafik lonjakan kasus yang signifikan, sejak diumumkannya kasus Covid-19 untuk pertama kali pada akhir Maret 2020 lalu. Bahkan NTB masuk dalam daerah yang digolongkan sebagai Zona Merah penyebaran Covid-19, hingga pada saat ini mulai mengalami penurunan. Upaya pencegahan meluasnya penyebaran virus ini, pemprov NTB melakukan beberapa langkah sesuai dengan arahan pemerintah pusat, mengeluarkan kebijakan pembatasan kegiatan masyarakat untuk belajar, bekerja dan beribadah dari rumah (Work From Home) dalam upaya memutus mata rantai penyebarannya. Dengan keterbatasan ini maka pola pemenuhan kebutuhan hidup masyarakat juga mengalami keterbatasan terlebih lagi dengan pemberlakuan PPKM ( Pemberlakuan Pembatasan Kegiatan Masyarakat).

Pandemi covid-19 yang terjadi belakangan ini telah membuat sektor usaha berproduksi, sehingga berimplikasi terhadap banyak aspek seperti modal habis dimakan, kelangsungan usaha jadi macet, tenaga kerja banyak yang menjadi pengangguran, sehingga mempengaruhi pertumbuhan ekonomi daerah. Kajian yang dibuat oleh Kementerian Keuangan menunjukkan bahwa pandemi COVID-19 memberikan dampak negatif bagi perekonomian domestik sepert penurunan konsumsi dan daya beli masyarakat, penurunan kinerja perusahaan, ancaman pada sektor perbankan dan keuangan, serta eksistensi UMKM. Pada aspek konsumsi dan daya beli masyarakat, pandemi ini menyebabkan banyak tenaga kerja berkurang atau bahkan kehilangan pendapatannya sehingga berpengaruh pada tingkat konsumsi dan daya beli masyarakat terutama mereka yang ada dalam kategori pekerja informal dan pekerja harian.

Terhentinya sebagian besar sektor perekonomian ini berdampak terhadap tingkat pemenuhan kebutuhan hidup masyarakat. Oleh karenanya harus jeli dan inovatif dalam melihat peluang ekonomi sebagai sumber daya yang bisa dimanfaatkan. Salah satunya adalah dengan memanfaatkan lahan pekarangan rumah. Usaha memanfaatkan lahan pekarangan dapat memberikan manfaat ganda yaitu secara ekonomis dan estetis. Desa Merembu Lombok Barat adalah salah satu desa dengan lahan pekarangan yang rata rata sangat luas dan bisa dimananfaatkan secara maksimal sebagai lahan ekonomis. Dengan melihat lahan yang luas namun pemanfaatannya yang masih belum maksimal maka perlu penanganan yang maksimal terhadap pemanfaatan lahan pekarangannya. Oleh karena itu, perlunya dilakukan sosialisasi pemanfaatan lahan pekarangan sehingga memberikan nilai ekonomis terhadap pemenuhan kebutuhan hidup keluarga akibat terdampak Covid 19.

\section{Metode}

Metode pelaksanaan kegiatan pengabdian masyarakat ini diawali dengan kegiatan sosialisasi pemanfaatan lahan pekarangan kepada masyarakat yang ada di Desa Merembu berfokus rumah tangga khususnya ibu ibu rumah tangga yang memang berdiam dirumah dan bisa memanfaatkan lahan pekarangan untuk menghasilkan tanaman sayuran dan tanaman buah-buahan lainnya sehingga bisa dijadikan sebagai penghasilan tambahan keluarga.

Metodenya ceramah, diskusi dan tanya jawab. Sosialisasi dilakukan dengan menyampaikan materi/konsep yang dapat diimplementasikan di lingkungan masyarakat. Peserta sosialisasi yang diundang terdiri dari Rumah Tangga dan kelompok anak anak muda yang ada di Desa Merembu.

\section{Hasil dan Pembahasan}

Kegiatan memanfaatkan lahan pekarangan rumah yang dilaksanakan di desa Merembu berlangsung selama dua hari, dengan jumlah peserta yang hadir sebanyak 20 rumah tangga baik yang diwakilkan oleh bapak bapak maupun oleh ibu rumah tangga beserta anak naka muda desa merembu. Lahan yang tidak terpakai diolah menjadi media untuk menanam berbagai macam jenis sayuran, buah dan tanaman obat obatan lainnya. Kegiatan ini dilakukan dengan beberapa tahapan yaitu edukasi melalui sosialisasi cara memanfaatkan lahan pekarangan dengan baik dan bernilai ekonomis dan pengenalan bibit sayuran, obat obatan dan buah buahan yanng cocok untuk di tanam di lahan pekarangan rumah. 


\section{a. Edukasi Pemanfaatan Lahan Pekarangan}

Memberikan edukasi melalui kegiatan sosialisasi kepada masyarakat di tempat yang telah disediakan oleh warga masyarakat setempat setelah dilakukan koordinasi dengan pimpinan desa

Kegiatan sosialisasi dilakukan selama satu hari. Materi yang diberikan kepada masyarakat, mengenai pemanfaatan lahan pekarangan dimulai dengan mengolah tanah di pekarangan rumah menjadi lahan yang dapat menghasilkan keuntungan ekonomis bagi keluarga. Selain itu juga sebagai sarana pemenuhan kebutuhan pangan keluarga serta pengenalan tanaman buah dan sayur sayuran serta obat obatan (apotik hidup ) bagi keluarga. Sosialisasi pada hari pertama memberikan edukasi mengenai cara mengelola dan memanfaatkan lahan pekarangan rumah yang selama ini tidak pernah dimanfaatkan, kegiatan ini berlangsung selama 2 (dua) jam dimana masyarakat aktif dalam sangat interaktif dan proaktif bertanya terkait cara pemanfaatan lahan pekarangan.

Pada hari kedua materi yang diberikan lebih mengacu pada pengenalan tanaman sayur sayuran, obat obatan dan buah buahan. Banyak dari warga yang tidak mengenal jenis sayuran yang mengandung gizi tinggi. Pengenalan jenis tanaman ini dikarenakan kurangnya informasi yang diperolehnya terkait jenis jenis sayuran.. Informasi yang disampaikan terkait sayur sayuran ini dimulai pada cara menanam sampai dengan memanennya. Edukasi yang diberikan kepada masyarakat yang ada di Desa Merembu melalui sosialisasi pemanfaatan lahan pekarangan yang bisa menghasilkan keuntungan secara ekonomis pada rumah tangga atau masyarakat yang memanfaatkan lahan pekarangannya secara maksimal.

Pemanfaatan Lahan pekarangan merupakan salah satu alternatif kegiatan yang dilakukan dengan harapan mampu untuk memenuhi kebutuhan akan buah buahan dan sayur sayuran. Dalam kegiatan ini masyarakat dapat menghasilkan produk olahan rumah tangga berupa sayur mayur yang mereka tanam pada lahan pekarangan rumah. Jenis tanaman yang dapat ditanam di lahan pekarangan diantaranya adalah tanaman sayur-sayuran, buah-buahan, obat-obatan, tanaman hias dan sebagainya. Selain dapat digunakan untuk konsumsi sehari hari, hasil panen dari lahan pekarangan juga dapat dijual untuk sebagai usaha sampingan anggota keluarga (Dwiratna et al., 2017)

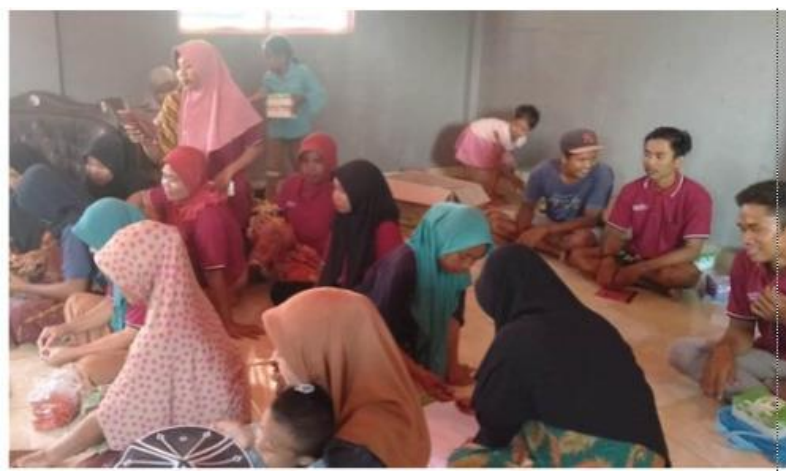

Gambar 1. Foto Kegiatan Edukasi Pemanfaatan Lahan pekarangan

Materi yang diberikan pada waktu kegiatan adalah memberikan motivasi kepada ibu-ibu bahwa pekarangan yang sempit bukan menjadi kendala untuk menghasilkan bahan pangan yang sehat, terutama sayur dapat dihasilkan dari halaman rumah. Selain memberikan kontribusi terhadap ekonomi keluarga, lahan pekarangan merupakan media penyeimbang dalam pelestarian sumber daya alam dan lingkungan hidup serta memberikan nilai estetis pada lingkungan sekitar rumah dengan tanaman bunga bunga hias.(Alqamari et al., n.d.)

\section{b. Penguatan Ketahanan Pangan}

Sistem ketahanan pangan di Indonesia secara komprehensif meliputi empat sub-sistem, yaitu: (i) ketersediaan pangan dalam jumlah dan jenis yang cukup untuk seluruh penduduk, (ii) distribusi pangan yang lancar dan merata, (iii) konsumsi pangan setiap individu yang memenuhi kecukupan gizi seimbang, yang berdampak pada (iv) status gizi masyarakat. Dengan demikian, sistem ketahanan pangan dan gizi tidak hanya menyangkut soal produksi, distribusi, dan penyediaan pangan ditingkat makro (nasional dan regional), tetapi juga menyangkut aspek mikro, yaitu akses pangan di tingkat rumah tangga dan individu serta status gizi anggota rumah tangga, terutama anak dan ibu hamil dari rumah tangga miskin. Lahan pekarangan merupakan salah satu wadah untuk menguatkan pangan keluarga.

Perlu adanya perubahan mind set masyarakay, agar yang namanya pangan itu tidak hanya sekedar beras, jagung, tapi ubi-ubian, sagu, dan lain-lain, perlu juga dibudidayakan untuk memenuhi kebutuhan pangan kita. Keanekaragaman pangan 
inilah yang mungkin bisa menjadi makanan alternatif untuk terbebas dari ancaman kelaparan. Dengan menanam tanaman yang menghasilkan gizi tinggi maka bisa mengakomodir kebutuhan gizi keluarga dari hasil tanaman pada lahan pekarangan. Hal ini sangat cocok untuk dikembangkan di Desa Merembu, karena lahan pekarangannya sangat potensial dari segi kesuburan tanah sehingga apa saja yang ditanam dapat tumbuh dengan baik.

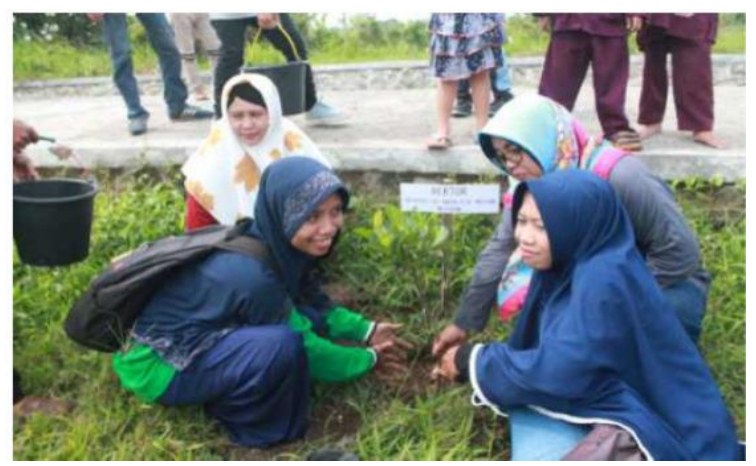

Gambar 2. Foto kegiatan Penguatan ketahanan Pangan melalui pemanfaatan Lahan pekarangan

\section{c. Penguatan Ekonomi Masyarakat}

Penguatan ekonomi Masyarakat pada masa pandemi membutuhkan usaha maksimal dan ekstra. Banyak yang kena PHK dan mengakibatkan banyaknya pengangguran. Pendapatan berkurang karena produksi yang semakin menurun. Mengharuskan untuk tetap bisa bertahan dalam kehidupan. Oleh karenanya dituntut untuk jeli melihat potensi potensi yang bisa dikembangkan dan mampu mengahsilkan uang. Penguatan ekonomi ini membutuhkan keterlibatan semua pihak dalam membangun pemulihan ekonomi dalam keluarga. Salah satu yang bisa dilakukan dengan memnafaatkan potensi lahan pekarangan yang ada sehingga mampu memberikan kontribusi terhadap pendapatan keluarga. Seringkali kita berpikir bahwa apa yang ada disekitar kita tidak memberikan manfaat yang berarti. Namun dalam kenyataannya potensi seperti lahan pekarangan justru bisa menghasilkan pundi pindi keuangan bagi keluarga apabila dimanfaatkan secara lebih maksimal.

Banyak bentuk pemanfaatan lahan pekarangan yang bisa dikembangkan oleh masyarakat terhadap pekarangan yang dimiliki, misalnya seperti pemanfaatan lahan pekarangan dalam bentuk pertanian atau perkebunan kelapa, pisang, palawija dan kangkung. Peternakan seperti, sapi, kambing, ayam dan itik. Dan bentuk usaha lainnya seperti usaha bengkel, jasa pengetikan komputer dan foto copy, konter hp, warung nasi jualan sembako, makanan ringan, pembuatan batu merah dan lain sebagainya. Dalam hal ini bentuk pemanfaatan lahan pekarangan yang ada di Desa Merembu tidak hanya dari segi bentuk usaha pertanian, perkebunan dan peternakan, akan tetapi ada juga dalam bentuk pemanfaatan lahan pekarangan seperti usaha sembako, bengkel, tempat pencucian mobil dan motor dan lain sebagainya yang memiliki prospek yang cukup bagus untuk mengelola lahan pekarangan dalam meningkatkan potensi ekonomi rumah tangga. Masyarakat banyak yang akhirnya memahami bahwa pemanfaatan lahan pekarang tidak hanya pada sektor pertanian tapi potensi pemanfaatan lahan pekarangan diluar bidang pertanian juga bisa digunakan untuk menambah pendapatan keluarga. Masyarakat terutama para ibu rumah tangga memiliki kecenderungan untuk ingin memanfaatkan lahan pekarangan menjadi lahan yang bisa dimanfaatkan sebagai ketahan pangan sehingga uang belanja dapur bisa menjadi teratasi atau bahkan bisa di tabung untuk digunakan pada kegiatan lain yang lebih bermanfaat dan lebih diprioritaskan. Bentukbentuk lain dari pemanfaatan lahan pekarangan yang dapat meningkatkan pendapatan salah satunya dapat berupa bentuk usaha lainnya seperti usaha jasa foto copy, warung makan, cafe mini dan lain sebagainya karena memiliki prospek yang cukup bagus untuk mengelola lahan pekarangan dalam meningkatkan potensi ekonomi rumah tangga yang ada. Desa merembu merupakan salah satu desa yang meiliki lahan pekarangan yang cukup luas untuk bisa dimaksimalkan bagi pemanfaatannya sesuai dengan kemampuan rumah tangga. 


\section{Kesimpulan}

Kegiatan Pengabdian masyarakat dilakukan untuk memberikan edukasi terkait pemanfaatan dan penggunaan lahan pekarangan menjadi beberapa manfaat diantaranya untuk bidanga pertanian yaitu pada penguatan sektor ketahanan pangan masyarakat, selain itu juga bisa dimanfaatkan untuk pengembangan usaha produksi dengan skala mikro, membuat bengkel mini, tempat pencucian motor atau mobil. Pemanfaatan ini bisa memberikan kontribusi maksimal terhadap pendapatan keluarga atau rumah tangga. Kegiatan ini membuat masyarakat antusias dikarenakan terpuruknya kegiatan perekonomian diikuti dengan perekonomian keluarga yang tidak stabil akibat Pandemi Covid 19 ini. Kebutuhan hidup yang semakin lama semakin meningkat di setiap harinya membuat masyarakat Desa merembu antusias dalam edukasi pemanfaatan lahan pekarangan ini. Ada celah yang bisa dimanfaatkan dari potensi asal yang berada pada masyarakat sendiri. Potensi ini selama ini abai untuk diperhatikan sehingga kegiatan eduksi dan sosialisasi pemnfaatn lahan pekarangan ini memberikan manfaat yang cukup besar bagi penegathuan masyarakat yang ada disekitar Desa Merembu Kabupaten Lombok Barat.

\section{Ucapan Terima Kasih}

Tim pengabdian pada masyarakat menyampaikan ucapan terima kasih kepada Universitas Nahdlatul Wathan yang telah memberikan ruang sehingga kegiatan pengabdian pada masyarakat ini. Kemudian Terimakasih juga kepada semua unsur yang terlibat dalam kegiatan pengabdian ini sehingga bisa dilaksanakan dengan lancar.

\section{Daftar Pustaka}

Alqamari, M., Trisna, N., \& Br, M. (n.d.). Optimalisasi Lahan Pekarangan Sebaga Sentral Tanaman Sayuran Pada Kelompok Ibu-Ibu Pengajian. 166-174.

Dwiratna, S., Widyasanti, A., \& Rahmah, D. M. (2017). Pemanfaatan Lahan Pekarangan Dengan Menerapkan Konsep Kawasan Rumah Pangan Lestari. Dharmakarya, 5(1), 19-22. https://doi.org/10.24198/dharmakarya.v5i1.88 73

Suharyanto, H. (2011). KETAHANAN PANGAN Heri Suharyanto * Abstrak. Sosial Humaniora, 4(2), 186-194. http://iptek.its.ac.id/index.php/jsh/article/view /633/355 